\title{
Remediation of leachate by composite NZVI-activated carbon in packed column
}

\author{
Eka Sri Yusmartini ${ }^{1 *}$, Muhammad Faizal $^{2}$, Marsi $^{3}$ \\ ${ }^{1}$ Chemical Engineering Department Faculty of Engineering Muhammadiyah University, 30263 Palembang, Indonesia \\ ${ }^{2}$ Chemical Engineering Department Faculty of Engineering Sriwijaya University, 30139 Palembang, Indonesia \\ ${ }^{3}$ Faculty of Agriculture Sriwijaya University, 30662 Inderalaya, Indonesia
}

\begin{abstract}
Improper solid waste management at final disposal site can cause in environtmental problem. The surrounding water bodies could be affected by leachate from the solid waste decomposition process because leachate contains high concentration of $\mathrm{BOD}_{5}, \mathrm{COD}$, ammonia, hydrocarbon suspended solid, and heavy metals. This problem has affected a final disposal site (named Sukawinatan) in Palembang, Indonesia, which did not implement leachate management system. This paper propose a method to reduce $\mathrm{BOD}_{5}, \mathrm{COD}$, Ammonia concentrations of the leachate in by applying composite nano zero valent iron (NZVI) - activated carbon for the remediation system of the surrounding area of Sukawinatan final disposal. The performance of the method was evaluated in this study using laboratory porous column apparatus. The results showed that the composite NZVI-activated carbon can be used to reduce concentration of pollutants from water bodies. The removal efficiency of this method on $\mathrm{BOD}_{5}, \mathrm{COD}$ and ammonia are $94.81 \%$, $92.81 \%$ dan $95.58 \%$ respectively.
\end{abstract}

\section{Introduction}

One current environmental problem is related to waste management. One of the most important environmental problems issues in Indonesia is groundwater contamination caused by improper waste management. In accordance to the Regulation No. 81 Year 2012 on Household Waste Management and Waste Household Waste kind in Indonesia the waste is usually brought to Final Disposal (TPA) site. While a small portion is recycled, the remaining stays as dumping.

In general, landfill leachate is defined as any contaminated liquid effluent percolating through deposited waste and emitted within a landfill or dump site through external sources [1], of which its route of exposure and toxicity often remains unknown [2]. The waste dumped in landfills will go through chemical and biochemical decomposition process. Rainfall and surface water percolating through the solid waste, could leachate out some of the hazardous constituents $[3,4]$. Indicated that the leachate usually contains COD (Chemical Oxygen Demand), BOD (Biochemical Oxygen Demand), ammonia, suspended solid hydrocarbon, and heavy metals concentrations. Leachate is also rich in phenols, nitrogen, phosphorus, which if not treated before it is discharged into the environment, will become a potential source soil and groundwater contamination [5].

As pointed by numerous researchers, leachate is a serious environmental problem to disharge heavy metals

Corresponding author: eka.yusmartini@gmail.com continuously, if it is not handled properly [ 6-12]. Landfill waste management using open dumping system without proper management of the leachate before dicharge into water bodies will lead to pollution of surrounding water bodies. Groundwater is one of the water resources that could be used as a raw material for various purposes for residential/domestic, agriculture, fisheries, livestock, and industrial. To overcome this problem, groundwater remediation should be implemented in the area surrounding the landfill.

Some researchers have carried out groundwater remediation effort to reduce the effect to reduce the effect of leachate various methods. Among others were, using Permeable Reactive Barrier to reduce heavy metals in leachate, such as $\mathrm{Mn}, \mathrm{Zn}, \mathrm{Cd}, \mathrm{Al}$, and $\mathrm{Cu}$ which respectively with reduction efficiency of $95.4 \%, 57.3 \%$, $64.3 \%, 54.0 \%$ and $30.8 \%$. Percent reduction of the parameters of nitrogen in the leachate reached $74.6 \%$, while the percent reduction of COD was $80.5 \%$ [13]. The use of activated carbon to the sequencing batch reactor (SBR) was reported by [4] where the leachate treatment process provides reduction of the COD by $66.1 \%$

More recently, the employment of membrane filtration technologies (ultrafiltration, nanofiltration, microfiltration and reverse osmosis) has emerged to be a justifiable and viable tool in pre-treatment or in patnership with chemical treatmens for elimination of colloids and suspended matters, and fractionation in evaluation of the pre ponderant molecular mass of 
organic pollutants in a given leachate, achieving a COD and heavy metals rejection coefficient value of 98 and $99 \%$, respectively $[4,14,15]$. On the contrary, the pressure-driven processes are subjected to the fouling effect by a wide spectrum of constituents (which requires extensive pre-treatment or chemical cleaning of the membranes, resulting in short lifetime of the membranes and decreases of process productivity) and a huge generation volume of concentrate (which is unusable and need further treatments [3].

Other for the remediation of polluted water leachate is by utilizing nanoparticles technology. This ecofriendly technology can be used for the sustainable management of groundwater resources [16]. Nanometersize nano particles have a great potential in the handling of water, waste and air pollution [17]. Research by [18] indicated that the use of organic NZVI resulted in large reduction of contaminants, not only by magnitude but also based on the rate of reduction.

This paper presents results of a study on the performance evaluation of NZVI-activated carbon composite from coconut shell in remediate waste leachate Sukawinatan Landfill in Palembang Indonesia. The surface area of activated carbon with high absorption capability was able to provide advantages in this composite system. Application of composite NZVIactivated carbon from coconut shell made using adsorption column. Parameters measured in this study were the reduction of leachate concentrations based on the reduction of $\mathrm{COD}, \mathrm{BOD}_{5}$, Ammonia as wel as $\mathrm{Pb}$ and $\mathrm{Cr}$.

\section{Experimental details}

\subsection{Materials and method}

The NZVI activated carbon composite used in this study was made of NZVI-Activated carbon with ratio 1:3 (w/w) the composition [19]. Leachates used in this research were taken from the Sukawinatan Landfill, Palembang, Indonesia.

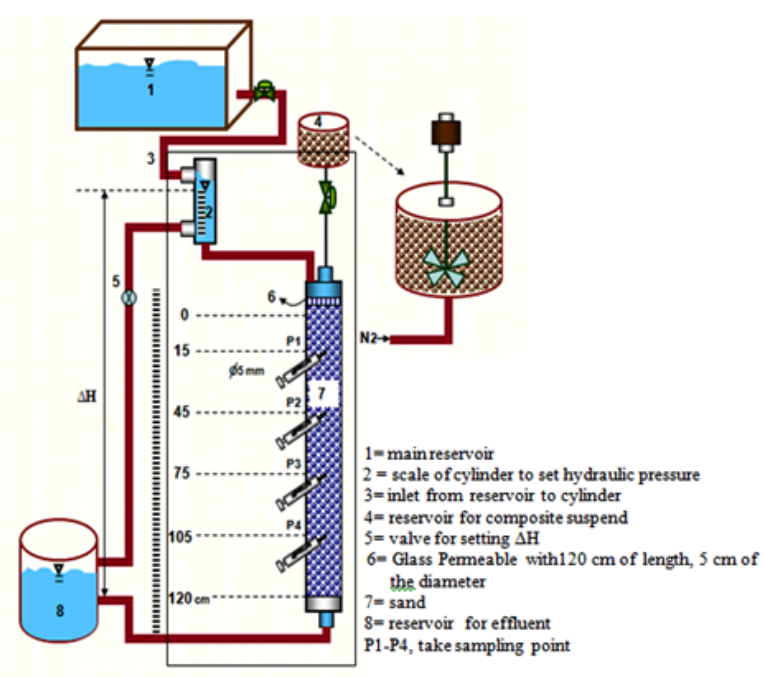

Fig 1. Packed Column Remediation
The study used laboratory porous column apparatus or packed column remediation apparatus as shown in Figure 1. This column with porous media was developed or modified based on the column used in previous study by Hosseini's column [20].

\subsection{Remediation using porous column apparatus}

The column done was made of $120 \mathrm{~cm}$ high glass cylinder with diameter of $5 \mathrm{~cm}$. The column was filled with sand. The particle size of the sand ranged from 2 $\mathrm{mm}$ to $1 \mathrm{~mm}$. The sand was compacted in the a glass cylinder. A stream of leachate was added manually to saturate the sand column from main reservoir. The concentration of the composite used in this study were 5, 8,11 and $14 \mathrm{~g} / \mathrm{L}$. The composite was streamed into columns with fixed nitogren gas flow so that the flow remains stable. Composite flow rate is set at a speed of 4 $\mathrm{mL} / \mathrm{min}$. Samples were taken simultaneously from four (4) sampling points along the glass cylinder. The locations of the sampling points were at 15, 45, 75 and $105 \mathrm{~cm}$ from the surface of the column. Remediation time was varied in 60, 120, 180 and 240 minutes.. The samples were evaluated by to measure the parameters analyzed $\mathrm{BOD}_{5}, \mathrm{COD}$, Ammonia and concentrations of $\mathrm{Pb}$ and $\mathrm{Cr}$.

\section{Result and discussion}

The initial concentration of each substance prior to treatment in the porous columns as compared to standard value are shown in Table 1.

Table 1. Concentration of hazardous elements from Sukawinatan Landfill Leachate as compare to standard range

\begin{tabular}{ccccc}
\hline Parameter & Unit & Value & $\begin{array}{c}\text { Quality } \\
\text { Standars*) }\end{array}$ & Comments \\
\hline $\mathrm{pH}$ & - & 5.65 & $6-9$ & $\mathrm{OK}$ \\
$\mathrm{BOD}_{5}$ & $\mathrm{mg} / \mathrm{L}$ & 924.00 & 50 & High \\
$\mathrm{COD}$ & $\mathrm{mg} / \mathrm{L}$ & 1664.00 & 100 & High \\
$\mathrm{Ammonia}$ & $\mathrm{mg} / \mathrm{L}$ & 47.52 & 1 & High \\
$\mathrm{Pb}$ & $\mathrm{mg} / \mathrm{L}$ & 2.40 & 0.1 & Low \\
$\mathrm{Cr}$ & $\mathrm{mg} / \mathrm{L}$ & 0.05 & 0.5 & High \\
\hline *) South Sumatera Governor Regulation Number 8 Year 2012
\end{tabular}

\subsection{Effect of weight composites and contact time on $\mathrm{BOD}_{5}$ reduction}

Based on Table 1, the percent reduction expected to achieve the Quality Standard suggested by South Sumatera Governor Regulation Number 8 Year 2012, the parameters $\mathrm{BOD}_{5}, \mathrm{COD}$, Ammonia, concentrations of $\mathrm{Pb}$ and $\mathrm{Cr}$ are $94.58 \%, 93.99 \%, 97.89 \%$ and 95.83 $\%$ respectively. The requirement should be met by varying contact time, the composite weight and sampling distance from the source. 
Effect of weight and time remediation to the percent reduction of $\mathrm{BOD}_{5}$ at all points of observation is shown in Figure 2. The figure indicates that the longer the contact time between the adsorbent with the adsorbate, the greater $\mathrm{BOD}_{5}$ absorbed. The highest reduction was achieved in the composite weight of $14 \mathrm{~g}$ and remediation time of 240 minutes. The reduction was $94.81 \%$ with a final consentration of $\mathrm{BOD}_{5}$ is $48 \mathrm{mg} / \mathrm{L}$ which meets the targets of Quality Standard that is $94.58 \%$.

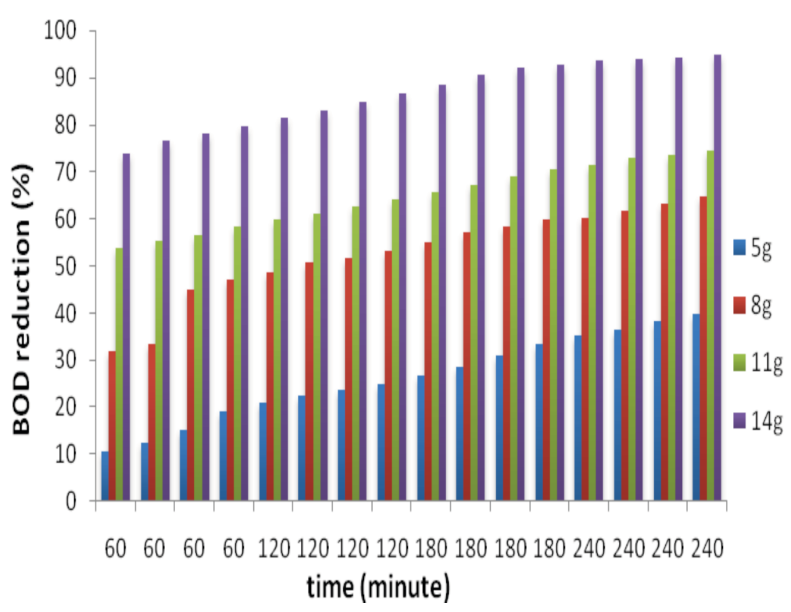

Fig.2. Effect of concentration of composite and contact time on $\mathrm{BOD}_{5}$ reduction

\subsection{Effect of weight composites and contact time to reduce COD}

The effect of composite weight and contact time on the percent reduction of COD is shown in Fig.3. The highest reduction was achieved with contact time of 240 minutes weight 14 g, i.e. of $92.49 \%$. Compared with the target of reduction that meets the target quality i.e. $93.99 \%$, thus more NZVI composite and longer contact time was require to meet the reduction targets.

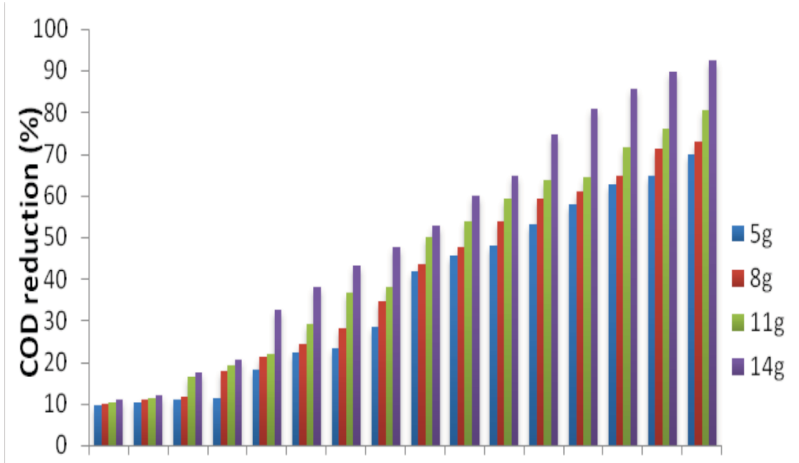

60606060120120120120180180180180240240240240 time (minute)

Fig.3. Effect of concentration of composite and contact time on COD reduction

$\mathrm{COD}$ and $\mathrm{BOD}_{5}$ is important indicators used to access the biodegrability of organic compounds [13]. The ability of composite NZVI-activated carbon to reduces the possibility of a break in the chain of carbon from complex organic compounds, so most of the organic compounds that are non-biodegradable were converted to biodegradable. Reduction of $\mathrm{BOD}_{5}, \mathrm{COD}$ on a variation of the weight of the composite or composite concentration shows a drastic change in the remediation of leachate pollutans proves that most of the non-biodegradable organic compounds has been converted into a biodegradable.

The analysis of the concentration of $\mathrm{Pb}$ and $\mathrm{Cr}$ resulted in leachate after remediation process was conducted using a concentration of $5 \mathrm{~g} / \mathrm{L}$, has not been detected again. This is supported by the results obtained by [24] to obtain a percent reduction of $100 \%$ NZVI weight concentration by used of $0.4 \mathrm{~g} / \mathrm{L}$. Research by [25] get maximum \% removal $\mathrm{Cr}$ was seen at time of $105 \mathrm{~min}$. in column studies.

The analysis indicates the relative reduction in the composite pollutant leachate. The stable composite was established during reduction of pollutant in leachate. Adsorption capacity of activated carbon and reactive characteristic of NZVI inside of composite caused suspended composite be able to stable in long times [22]. The NZVI-activated carbon composites combine the physical adsorption capacity of activated carbon with the destructive reactivity of NZVI and can be used as a reactive activated carbon, which is not subject to the limitations of using activated carbon and NZVI separately [23].

\subsection{Effect of weight composites and contact time to reduce ammonia}

The influence of weight and contact time on the concentration of ammonia at all points of the observations is shown on Fig.4. In the figure, it shown that the longer the time of contact time between the adsorbents with adsorbate, the greater the ammonia absorbed.

The highest reduction was achieved on heavy use of composite $14 \mathrm{~g}$ with 240 minutes of contact time with the reduction of ammonia $95.58 \%$. Compared with the target of reduction that meets the target quality i.e.97.89 $\%$, thus more NZVI composite and longer contact time was require to meet the reduction targets.

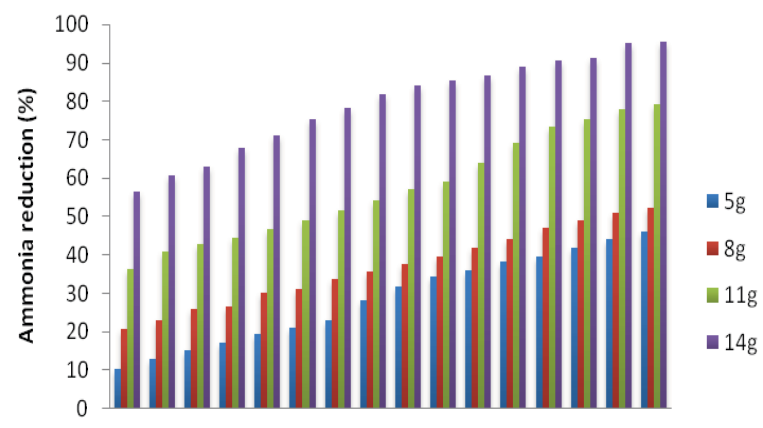

60606060120120120120180180180180240240240240

time (minute)

Fig.4. Effect of concentration of composite and contact time on ammonia reduction 
Based on the results of a composite application against leachate on remediation, the column reached percent reduction on the parameters of $\mathrm{BOD}_{5}, \mathrm{COD}$ and Ammonia as shown in Table 2. Reduction of BOD, COD and ammonia content in leachate were measured by the difference between initial concentration by each of pollutant's elements.

Results of analysis of $\mathrm{Pb}$ and $\mathrm{Cr}$ concentrations in leachate post remediation process performed using a concentration of $5 \mathrm{~g} / \mathrm{L}$ was no longer detectable. These results are supported by the results obtained [24], get a $100 \%$ percent reduction using NZVI heavy concentration of $0.4 \mathrm{~g} / \mathrm{L}$. Reduction is the predominant mechanism for $\mathrm{Pb}$ and $\mathrm{Cr}$ removal [26].

Table 2. Reduction NZVI- activated carbon composite in leachate remediation

\begin{tabular}{lccc}
\hline Parameter & $\begin{array}{c}\text { Initial } \\
\text { concen.(mg/ } \\
\mathrm{L})\end{array}$ & $\begin{array}{c}\text { Final } \\
\text { concen. } \\
(\mathrm{mg} / \mathrm{L})\end{array}$ & \% Reduction \\
\hline $\mathrm{BOD}_{5}$ & 924 & 48 & 94.81 \\
$\mathrm{COD}$ & 1664 & 125 & 92.49 \\
Ammonia & 47.52 & 2.1 & 95.58 \\
\hline
\end{tabular}

Results from this study, it is resulted that the stability of the composite in reducing pollutants leachate. The role of activated carbon that maintains the stability and form a barrier sorption and reactivity NZVI can maintain the stability of the suspension in a long time [22]. Percent reduction of the composite to heavy metals $\mathrm{Pb}$ and $\mathrm{Cr}$ reaches $100 \%$.

The reduction of $\mathrm{BOD}_{5}$ and $\mathrm{COD}$ reached respectively at $94.81 \%$ and $92.49 \%$ on the weight of the composite $14 \mathrm{~g} / \mathrm{L}$ of contact time of 240 minutes, while [21] get a percent reduction of $\mathrm{BOD}_{5}$ and COD respectively $35 \%$ and $47.94 \%$ by weight of $2.5 \mathrm{~g} / \mathrm{L}$., while [13] getting percent reduction of COD in leachate $66.8 \%$ using ZVI and $80.5 \%$ use zeolite media and ZVI on permeable reactive barrier system.

\section{Conclusion}

The results obtained in the process of remediation using NZVI-Activated Carbon prove that composites in 1:3 ratio is aneffective substance to be used for groundwater remediation of contaminated water by leachate from landfil. The substance was mixed with contaminated water in a porous column with a contact time of 240 minutes. In particular composite number, the performance of the adsorbent is relatively increased because it is supported by the stability and high absorption, besides their reactivity makes composites capabilities do not only absorb but also reduce the amount of contaminants. The removal efficiency of this method $\mathrm{BOD}_{5}, \mathrm{COD}$ and Ammonia are $94.81 \%, 92.49$ $\%, 95.58 \%$ respectively.
The authors would like to acknowledge all support coming from Management of Sukawinatan Landfill in Palembang and National Nuclear Energy Agency of Indoensia (BATAN) for supporting and advocationg the process of NZVI synthesis and analysis.

\section{References}

1. M.E.Taulis, Resolution Press, Christchurch, 173190 (2005).

2. L. Koshi, E. Paris, S.Ling, T. Jones, K. Beruhe, Sci. Total Environ, 384:171-181 (2007).

3. S. Renoua, S., J.G Givaudan, S. Poulain, F. Dirassouyan and P. Moulin. J. Hazard Mater. 150:468-463 (2008)

4. K.Y. Foo, and B.H. Hameed. J. Of Hazardous Materials, 171:54-60 (2009)

5. T.H. Christensen., P. Kjeldsen and P.L. Bjerg. J. Appl.Geochem. 16:659-718 (2001)

6. H. Fan, H. Shu, HS. Yang, Wc.Chen, J. Science of Tot. Envi. 36:25-37 (2006).

7. R.S. Sletten, M.M. Benjamin, JJ.Horing, JF Ferguson. J. Water Res. 29(10):237-86 (1995)

8. T. Urase, M.Salequzzaman, T. Matsuo, K. Yamakomo, N. Suzuki, Water Scie. Technol., 36(12):349-356 (1997).

9. J.B. Christensen, DL.Jensen, C. Gron, Z. Fulip, TH. Christensen, J. Water Res. 32(1): 125-135 (1998).

10. K. Fytianos, B. Tsaniklidi, Env.Int. 24(4):477-86 (1998).

11. JC. Chen, MY. Wey, YC. Lin, J. Chemosphere 37(13): 2617-25 (1998).

12. CS. Poom, ZQ. Chen. J. Chemosphere 38(3):663680 (1999).

13. D.Jun., Z. Yongsheng., Z. Weihong and H. Mei.. Journal Of Hazardous Materials 161: 224-230 (2009).

14. K. Ushikoshi, T. Kobayashi, K. Dematsu, A. Toji, D. Kojima, K. Matsumoto, J. Desalination 150: 121129 (2002).

15. D. Trebounet, J.P. Schlumpf, P. Jaouen, F. Quemeneur, J. Water Res. 35:2935-2942 (2001).

16. D. Grienger., A. Fjordboge, N.B. Hartman, E.Eriksson,. Journal Of Contaminant Hyd. 118, 165183 (2010).

17. X. Li., D. Elliot and W. Zhang.. Critical Reviews In Solid State And Materials Science. 31:111122(2006).

18. W. Zhang, and W.E. Daniel. Applications Of Iron Nanoparticles For Groundwater Remediation. Published Online In Wiley Interscience (2006).

19. E.S. Yusmartini., D.Setiabudidaya.,Ridwan, Marsi, Faizal. Journal Advanced Materials Research 62-65 (2015).

20. S.M. Hosseini., A.B. Ashtiani and M. Kholgi. Journal Desalination .276:214-221 (2011).

21. Z.E. Kashitarash., S.M. Taghi, N. Kazem, A. Abbas and R. Alireza. Iranian Journal of Environmental Health Science and Engineering. 5: 9-36 (2012).

22. K. Mackenzie., Schierz, A., Georgi, A., and 
23. Kopinke, F.D. Journal Global Nest, 10(1):54-61. (2008).

24. HH.Tseng, JG Su, C. Liang, J. of Hazardous Materials, 192:500-506 (20110.

25. N. Shao-feng, I. Yong, X. Xin-Hua, J. Zhejang Univercity Science, 10:1022-1027 (2005).
26. S.H. Rahmi, G.M. Madhu, AA, Kittur and R. Surresh, International J. of Current Engineering and Technology, 37 (2013).

27. X. Li, W. Daniel, W. Elliot and W. Zhang, Critical Reviews in Solid State and Material Science, 31:111-125 (2006) 